\title{
A FENNTARTHATÓSÁG GYAKORLATI MÜKÖDÉSÉNEK ÖSSZEFÜGGÉSEI A MAGYAR SZÁLLODA SZEKTORBAN
}

\author{
${ }^{1}$ Gyurácz-Németh Petra $-{ }^{2}$ Hiezl Kitti $-{ }^{3}$ Németh Marietta $-{ }^{4}$ Búr Renáta \\ ${ }^{1}$ Pannon Egyetem, nemeth.petra@gtk.uni-pannon.hu \\ ${ }^{2}$ Pannon Egyetem, hiezl.kitti@gtk.uni-pannon.hu \\ ${ }^{3}$ Pannon Egyetem,n.mari@freemail.hu \\ ${ }^{4}$ Pannon Egyetem volt hallgató, burrency@hotmail.com
}

DOI: $10.15170 / T V T .2021 .06 .02 .02$

\begin{abstract}
Absztrakt
A fenntarthatóság témaköre egyre fontosabb szerepet játszik a vállalkozások életében. A gazdasági, társadalmi és környezeti problémáknak mind okozója, mind elszenvedője a turizmus, ezen belül pedig a szálloda szektor.

Jelen kutatás a fenntarthatóság gyakorlati vonatkozásait vizsgálja, rávilágít az olyan összefüggésekre, amelyek a fenntarthatóság három pillére közötti különbségtételre, a szállodalánc tagság és a fenntarthatóság kapcsolatára, a stratégia illetve minősítés kapcsolatára, valamint a fenntarthatósági stratégia kialakítására és betartatására irányul.

A kutatás során 78 érvényes kérdőív érkezett vissza, amelyet a szállodaigazgatók töltöttek ki. Az eredmények értékelése után megállapítható, hogy a hangsúly a gazdasági fenntarthatóságon van, ezt követi a környezeti vagy a társadalmi pillér. A szállodalánc és a fenntarthatósági stratégia megléte között egyértelmü összefüggés van, és szintén fontos kapcsolatot találtak a kutatók a fenntarthatósági stratégia kialakítója és betartatója között. A társadalmi tényezö akkor válik fontossá a szálloda életében, ha egy részlegvezető felel érte, tehát minél inkább az igazgató felelőssége a fenntarthatósági stratégia, annál kevésbé fontos a társadalmi pillér.
\end{abstract}

Kulcsszavak: fenntarthatóság, szálloda szektor, stratégia

\begin{abstract}
Sustainability plays a more and more important role in the everyday operation of companies. The tourism and the hotel sector are able to cause economic, social and environmental problems although the industry is also suffering from the effect.

This research focuses on the practical implications of the sustainability, it reveals the relations as the difference between the pillars of sustainability in the minds of hotel managers. It makes a correlation between hotel affiliation and a sustainable strategy as well as the link between a certification and the existence of a strategy in the hotel. The research also emphasizes the role of the person who creates the sustainability strategy and who has to enforce it.

The research resulted 78 questionnaires filled by hotel general managers. After the analysis it can be stated that the hotel managers focus on economic sustainability, the second most important is the environmental then the social pillar. Hotel chain member hotels tend to implement a sustainability strategy and according to the result there is a correlation between the role of the creator and the enforcer of the sustainability strategy. The social pillar gets more emphasis the operation of the hotel if a department leader is responsible for it, instead of the hotel general manager.
\end{abstract}

Keywords: sustainability, hotel sector, strategy 


\section{Bevezetés}

A fenntarthatóság kérdése a turizmus és különösen a szálloda szektorban mind a vállalat (BHOCHHIBHOYA et al. 2019, ASADI et al. 2020, DANI et al. 2021), mind a fogyasztók (PRUD'HOMME, RAYMOND 2013, D’ACUNTOA et al. 2020, LATIF et al. 2020 szempontjából fontos és kutatott kérdéssé vált.

Számos kutatás bizonyította, hogy a turisták is egyre inkább érdeklődnek a környezettudatos termékek iránt (BUFFA et al. 2018; PENG et al. 2019), ami a fenntarthatóság egyik, talán legkézzelfoghatóbb eleme. A szektor keresleti oldalán már tanulmányok bizonyítják, hogy az emberek nemcsak a környezetvédelemért, hanem a zöld termékekért és szolgáltatásokért is hajlandóak akár többet is fizetni (KANG et al. 2012).

A fenntarthatóság tehát bizonyítottan jelen van a keresleti tényezők között, emellett a kínálati oldalon is egyre inkább megjelenik. Ennek kézzelfogható, gyakorlati jelei elsősorban a szállodaláncok esetében láthatóak a nyilvánosság számára is, ilyen például jelenleg a világ legnagyobb szállodalánca, a Marriott International (https://serve360.marriott.com/). A kutatások leginkább a turizmus vagy szálloda fenntarthatóságának fejlesztésére koncentráltak, míg a működés kissé elhanyagolt területként azonosítható (REID et al. 2017).

Jelen kutatás célja a szállodák müködésének és a fenntartható gyakorlatoknak, illetve ezek alkalmazásának vizsgálata a magyar szállodák esetében. A tanulmány kiemelten koncentrál az olyan stratégiai kérdésekre, mint a fenntarthatósági pillérek különböző fontossága, valamint az operatív menedzsment feladatokra, amelyek a fenntarthatósági intézkedések betartására és betartatására irányulnak. A kutatás még a COVID-19 járvány előtti állapotokat tükrözi.

\section{Szakirodalmi áttekintés}

1987-ben az ENSZ felkérésére a Brundtland-bizottság készítette el „Közös jövőnk” címmel azt a jelentést, amelyben a fenntarthatóság újszerü fogalomként jelent meg a szakirodalomban. Ebben a fenntarthatóság komplex jelentéstartalommal bír, amelynek értelmében a jelen generációinak igényeit olyan módon szükséges kielégíteni, hogy az gyakorlatilag biztosított legyen a jövő generációinak számára is (KEREKES 1998).

\subsection{Fenntarthatóság a turizmusban}

A turisztikai szektor vonatkozásában elsőként a Világturisztikai Szervezet (WTO) használta a fenntarthatóság fogalmát 2005-ben. Ennek értelmében az idegenforgalmat a szakmai szervezet olyan turisztikai jelenségként definiálja, amely a gazdasági, társadalmi és környezeti hatásokat is figyelembe veszi, beleértve a turistákon kívül a kapcsolódó iparágak, a helyi közösségek és a környezet igényeit is (UNEP-WTO 2005).

A szakirodalomban témához szorosan kapcsolódó fogalmak az olyan angol kifejezések, mint „Triple Bottom Lines” (magyarul hármas célrendszer/eredménykritériumok), valamint az SDG (,Sustainable Developement Goals”, vagyis Fenntartható Fejlödési Célok). A hármas pillér a fenntarthatóság biofizikai, szociális és gazdasági alapköveit jelenteni, vagyis maga a fogalom eme három dimenzió mentén értelmezhető és definiálható. (HACKING - GUTHRIE, 2008). Fontos kiemelni, hogy egy-egy vállalat számára nem csak és kizárólag a pénzügyi mutatók a relevánsak, hanem a pénzügyi teljesítmény mérése mellett a szociális és a környezeti aspektusok monitorozása is elengedhetetlen. Érdekes megközelítést jelenthet, amennyiben minden egyes mutatót azonos súlyokkal vesz számításba adott vállalkozás és a fenntarthatóság jelenlétét, valamint mértékét a három halmaz metszete adja. Létezik ugyanakkor olyan modell is, amely a felsorolt pilléreket egymásba ágyazódva (környezet - társadalom - gazdaság) értelmezi (FLEISCHER 2014). 
A Fenntartható Fejlödési Célok definícióját 2015-ben deklarálta az ENSZ az Agenda 2030 program keretén belül, amely a gyakorlatban integrált fejlődési és fejlesztési keretrendszert jelöl a nemzetek számára a benne megfogalmazott 17 céllal és 169 részcéllal. Az alcélokat tömörítő fö célcsoportok a következőek:

- a szegénység felszámolása,

- az éhezés megszüntetése,

- egészség és jóllét,

- minőségi oktatás,

- nemek közötti egyenlőség

- tiszta víz és alapvető köztisztaság,

- megfizethető és tiszta energia,

- tisztességes munka és gazdasági növekedés,

- ipar, innováció és infrastruktúra,

- egyenlőtlenségek csökkentése,

- fenntartható városok és közösségek,

- felelős fogyasztás és termelés,

- fellépés az éghajlatváltozás ellen,

- óceánok és tengerek védelme,

- szárazföldi ökoszisztémák védelme,

- béke, igazság és erős intézmények,

- partnerség a célok eléréséért (KSH, 2020).

A turizmus fenntarthatósága csak akkor lehet hosszú távon sikeres, ha mind a gazdasági, társadalmi és a környezeti fenntarthatóságot is képes menedzselni holisztikus módon. Az ökológiai látásmód határozza meg a desztináció természetes erőforrásainak környezeti minőségét, amely elemek az attrakciók lényegi elemeit adják. Amennyiben ezek az erőforrások kimerülnek vagy kompromittálódnak, akkor annak közép- és hosszú távú hatása lehet a turistaérkezések számára és a desztináció sikerességére. A szociokulturális pillér azt mutatja, hogy egy terület a társadalmi, kulturális örökségével tud-e fontos szerepet játszani a turizmusban. A legnagyobb veszély a témakör vonatkozásában, hogy a helyi tradíciók eltünnek, eltünhetnek a turizmus hatására, és egyre nagyobb lesz a nemzetközi cégektől való függőség. A gazdasági pillért tekintve elmondható, hogy a nem-fenntartható turizmusfejlesztés olyan társadalmi és környezeti költségeket eredményez, amelyek hosszú távon magasabbak, mint a gazdasági nyereség (CASTELLANI 2009).

A turizmus kétféle céllal alkalmazza a fenntarthatósági gyakorlatot. Az egyik cél a negatív környezeti hatások csökkentése a kibocsátás és szemét mennyiségének mérséklése által. A második cél az erőforrások fenntartható használata és megóvása a klímaesemények szektorra vonatkozó hatásának minimalizálása érdekében (REID et al. 2017).

\subsection{Fenntarthatóság a szálloda szektorban}

A fenntartható szálláshely-szolgáltatás a szálloda szektor olyan irányú fejlesztése, amely amellett, hogy a jelenlegi vendégek, szállodai dolgozók illetve egyéb érintett partnerek igényeit kielégíti, a jövő vendégeinek, szállodai dolgozóinak és egyéb érdekelt feleknek is lehetővé teszi, hogy élvezni tudják ugyanazokat a termékeket és élményeket (SLOAN et al. 2012).

A szállodai terjeszkedés bizonyos területeken erősen károsította a környezetet. A szálloda szektorra egyértelmüen igaz, hogy jelentősen hozzájárul a negatív hatásokhoz, amelyek a környezetet érik, mivel hatalmas mennyiségü elektromos energiát és vizet fogyasztanak a hütés-fútésen, a világításon és akár a mosodai szolgáltatáson keresztül is (SANTOS et al. 2020). 
Azonban a környezeti fenntarthatósági pillér még mindig eltörpül a gazdasági pillér hatalmas szerepe mellett. A szállodák kifejezetten nagy állandó költségállománnyal rendelkeznek, amely magas müködési kockázatot jelent a vállalatok számára. A magas költségek miatt ezek a létesítmények nagyon érzékenyek az üzleti környezet változására, legyen ez akár egy gazdasági recesszió vagy értékesítési volumencsökkenés, ami nagyban befolyásolhatja a jövedelmezőséget (MUCHARREIRA 2019).

A fenntarthatósági pillérek között kapcsolatot is vizsgáltak és találtak a kutatók, amikor különbözö szempontokat szem elött tartottak, a szállodákat téve a kutatásuk fókuszába. A fenntarthatóság nemcsak kötelesség, vagy felelősségvállalási tényező, hanem egyértelmüen üzleti döntés is, mivel KULARATNE et al. (2019) publikációjukban bizonyították, hogy a környezeti fenntarthatóság és felelősségvállalás erősíti a szállodák hatékonyságát - különösen az energiafogyasztást és a vízfelhasználást tekintve. GYURÁCZ-NÉMETH (2014) is össze tudta kapcsolni a két fenntarthatósági pillért azzal, hogy a környezettudatosság fö motiváló tényezőjeként a költségmegtakarítást nevezte meg, továbbá ASADI et al. (2020) pedig a zöld innovációk hatását vizsgálták a szállodák müködésének vonatkozásában. Pozitív és szignifikáns kapcsolatot találtak a zöld innovációs folyamatok és a környezeti teljesítmény között, tehát ha a szálloda „zöld" fejlesztési folyamatban érintett, akkor elfogadhatóbb környezeti teljesítményt képes elérni. Ezzel egyfajta ösztönző erőt generáltak a kormányzati és iparági feltételeknek való megfelelés kapcsán, illetve sikerült elérni a pazarlás és szennyezés mértékének csökkentését, amivel a környezetet is védik és egyidejüleg még a versenypotenciált is erösítik (ASADI et al. 2020). A szállodák környezetvédelemmel kapcsolatos döntései kétségtelenül számos hasznot hozhatnak a cégeknek. A zöld innováció a szállodai teljesítmény mind környezeti, mind gazdasági aspektusát befolyásolni tudja; az ilyen típusú fejlesztések rengeteg pénzt takaríthatnak meg a szállodák számára, ugyanakkor vonzóvá is teszi öket a környezettudatos fogyasztók körében (ASADI et al. 2020).

Általánosságban megállapítható, hogy a globalizációs folyamatok felerösödésével a multinacionális vállalatok határokon, olykor kontinenseken átívelö térnyerése okán a globális verseny is felerősödik. Annak érdekében, hogy egy adott szállodalánc versenyképességét megörizhesse, a komplex felelősségvállalás jegyében a társadalmi és a környezeti aspektusokat is figyelembe kell vennie. Nem csak a beszállítói kör lojalitásának elérése a cél, hanem adott vállalatnak meg kell nyernie a helyi dolgozói kör bizalmát és támogatását is (WANG et al, 2020). A tanulmány tematikáját tekintve a fenntarthatóság és a globalizáció fogalmak kapcsolatrendszeréről való említés nélkül nem lehetne teljes körü. A gazdasági növekedés és a szabad kereskedelmi feltételek megteremtése nagymértékben hozzájárult egy globális méreteket öltő, fogyasztói társadalom kialakulásához, eme folyamat már az 1980-as években kezdetét vette - generálva ezáltal negatív tendenciákat is (példaként említve negatív biológiai folyamat a biodiverzitás csökkenése (REES 2002).

Akár független, akár szállodaláncbeli intézményröl lévén szó, a vállalati stratégia - szóbeli vagy lánctagság esetén javarészt írásbeli része - tartalmazza a gazdasági aspektuson felüli társadalmi és környezeti elemeket. A jogi szabályozások, a környezetvédelmi irányelvek előtérbe kerülése és az egyre nagyobb publicitási faktor a gyakorlatban is megköveteli a szállodáktól, hogy fenntartható módon fejlesszék vállalataikat (JONES et al. 2013). Míg egy szállodalánc esetében felülről jövő utasítás értelmében szükséges a fenntarthatósági stratégiával kapcsolatos tevékenységekről, elért eredményekről referálni; addig kisebb, önálló szállodák esetében ad-hoc projektek jellemzőek, és számtalan esetben monitorozási feladatok elvégzésére sincs szabad emberi erőforrás (KHATTER et al. 2019).

A gazdasági pillér megkérdőjelezhetetlen fontosságát hangsúlyozza több publikáció is (ALZBOUN et al. 2016, MUCHARREIRA et al. 2019). A szállodák életében egyértelmüen ez a fő aspektus befolyásolja a mindennapokat, amely a fenntarthatóság megítélésében is meghatározó lehet. A hatékonyság kérdését szintúgy vizsgálja a nemzetközi szakirodalom (KULARATNE et al. 2019). 
Jelen kutatás ezekhez a témákhoz kapcsolódik, részletesebben és gyakorlatiasabban taglalja a fenntarthatóság szállodai menedzsment kérdéseit és hozzá kíván járulni a stratégián túl az operatív megvalósítás kihívásaira adott válaszok széles, releváns köréhez is.

\section{Módszertan}

A kutatás elsődleges célja a különböző fenntarthatósági gyakorlatok vizsgálata a magyar szállodák esetében, amelynek során különös hangsúlyt fektet a fenntarthatóság pilléreinek fontosságára, valamint olyan praktikumbeli kérdésekre, mint a stratégia kialakítása és betartatása.

A kutatás során az alábbi hipotéziseket fogalmazták meg a kutatók:

1. A magyar szállodák igazgatói számára a gazdasági fenntarthatósági pillér a legfontosabb, ezt követi csak a másik kettö, tehát a társadalmi és környezeti pillér.

A hipotézis indoklása elsősorban a magyar szálloda szektor jellemzőire vezethető vissza. A gazdasági megtérülés, illetve a hosszú távú pénzügyi fenntarthatóság biztosítása elsődleges jelentőségü, és minden más intézkedés alapjának tekinthető (GYURÁCZ-NÉMETH 2014).

2. A magyar szállodák esetében a szállodalánc tagság és a fenntarthatósági stratégia megléte között összefüggés van.

A szállodaláncok súlya a fenntarthatóságról való gondolkodás, és alapvetően a fenntarthatóság elveinek figyelembe vétele szempontjából is releváns (CHEN 2019; WANG et al. 2020; ÁSVÁNYI et al. 2020). Egy szállodaláncról ennek alapján feltételezzük, hogy rendelkezik fenntarthatósági stratégiával, annak érdekében, hogy az ilyen irányú céljait megvalósítsa.

3. A magyar szállodák esetében a fenntarthatósági stratégia kialakítója és betartatója között kapcsolat van.

Fontos kérdés a fenntarthatóság gyakorlati alkalmazása szempontjából, hogy a stratégia maga milyen esetben tartható be hatékonyan. Szállodai tapasztalat alapján pedig felmerült az a vizsgálandó kérdéskör, hogy a stratégia kitalálója és betartatója között kapcsolatot lehet-e azonosítani.

4. A magyar szállodák müködése során a fenntarthatóság társadalmi tényezője akkor válik fontossá, ha egy részlegvezetö a felelös a társadalmi pillér megvalósításáért.

A szállodák müködését tekintve egyértelmü a részlegvezetők jelenlétének és munkájának súlya az operatív megvalósításban (WANG et al. 2020). A társadalmi pillérrel valószínüleg jobban szembesül egy vezető, aki közvetlenül dolgozik a végrehajtó személyzettel, hiszen mind a személyes, mind a munkából származó szakmai kihívásait, attitüdjét ismeri a munkavállalói körnek.

A hipotézisek vizsgálata során igyekezett a kutatói csapat fényt deríteni a szállodalánchoz tartozó és független szállodák közötti különbségre, valamint a láncszállodák fenntarthatósági müködésének okaira is. A kutatás egyben magyarázó és kvantitatív, ennek értelmében mennyiségi adatok kerültek összegyüjtésre a fent említett kapcsolatok vizsgálata érdekében. A cél elsősorban az összefüggések, azok szorosságának és irányának feltárása volt.

A szállodák megkeresése kérdőív segítségével történt, amely LimeSurvey rendszerben készült, és elektronikusan került kiküldésre a szállodák részére. Ennek kitöltésére a téma komplexitása miatt a szállodaigazgató, mint felsővezető tekinthető alkalmasnak, ezért a kérdőív linkjét tartalmazó emailt a szállodák igazgatói kapták meg.

A két hónapot felölelő kitöltési időintervallum során telefonos és személyes segítséget is nyújtottak a kutatók. Jelen cikk a kérdőív egy részének eredményei alapján készült.

A minta kiválasztásának kritériumai a következők voltak:

- Magyarországon található a szálloda,

- 1-5 csillagos szálloda a Hotelstars minősítési kritériumrendszer alapján,

- Müködő szálloda,

- Szálloda szerepel a Booking.com adatbázisában. 
A kérdőív összesen 606 szálloda igazgatójának került kiküldésre és 78 érvényes kitöltés érkezett vissza, vagyis a kitöltési ráta $12,87 \%$ volt. A kérdések közötti kapcsolatok megállapításához Spearman-féle rangkorrelációt használtak a kutatók, mivel az adatok alacsony mérési szintü változókként kezelendök. A Spearman-féle rangkorreláció a Pearson-korreláció egy nem parametrikus változata. Spearman korrelációs együtthatója két rangsorolt változó közötti asszociáció erősségét és irányát méri. Ugyan a Spearman rangkorrelációs teszt nem tartalmaz feltételezéseket az adatok megoszlásáról, de alacsony mérési szintű változók esetén alkalmazható (Correlation - Pearson, Kendall, Spearman - Statistics Solutions, 2020). A mutató értéke nem csak a kapcsolat erősségét, de annak irányát is megmutatja (MOLNÁR 2015). Spearman esetében a 0,10 és 0,29 közötti korrelációs együtthatók kis asszociációt, a 0,30 és 0,49 közötti együtthatók közepes asszociációt, a 0,50 és ennél magasabb együtthatók pedig nagy asszociációt vagy viszonyt jelentenek (Correlation - Pearson, Kendall, Spearman - Statistics Solutions, 2020).

\section{Eredmények, következtetések}

A kutatás eredmények interpretációja szempontjából releváns információ, hogy a Covid-19 világjárvány előtt történt a felmérés.

A kutatásmódszertanban leírtak alapján kiválasztásra kerültek a kutatásba meghívott szállodák. A kutatás levezetése során 78 érvényes kérdőív gyült össze online kérdőív formájában. A kutatásban részt vett szállodák megoszlása, fó profiljuk tekintetében 24 városi szálloda, 13 wellness, 11 konferencia és 6 boutique szálloda. Ezen felül 7 szálloda választotta az egyéb lehetöséget, ezek közül 3 a borhotelt jelölte meg szállodájának típusaként. Minőségi besorolásukat tekintve a szállodák többsége, 52,6\%-a négy csillagos. A résztvevők közül 5 szálloda két csillagos, 29 szálloda három csillagos, 41 szálloda négy csillagos és összesen 3 szálloda öt csillag besorolású. Ezek közül 45-en tagjai a Hotelstars Unionnak. A kutatásban részt vett szállodák közül 22 pedig tagja szállodaláncnak.

\subsection{Kutatás eredményei}

$\mathrm{Az}$ eredményeket statisztikai módszerek segítségével tesztelte a kutatócsoport. A változók többnyire alacsony mérési szintủek, így a hipotézisek tesztelésénél a megfelelő módszertan fontos szempont volt. Az eredmények hipotézisenkénti sorrendiségben kerülnek bemutatásra.

1. A magyar szállodák igazgatói számára a gazdasági fenntarthatósági pillér a legfontosabb, ezt követi csak a másik kettö, tehát a társadalmi és környezeti pillér.

Az első hipotézis célja annak megállapítása volt, hogy a magyar szállodák müködése során melyik fenntarthatósági pillérre fordítanak nagyobb figyelmet, illetve mi a fenntarthatósági tényezők közötti fontossági sorrend. 


\section{1. ábra: Fenntarthatósági tényezők}

\section{Az alábbi fenntarthatósági tényezők közül melyikre fordít figyelmet az adott szálloda?}

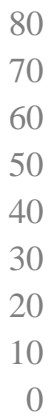

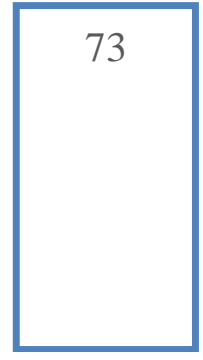

Gazdasági

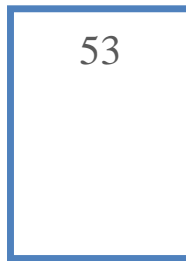

Társadalmi

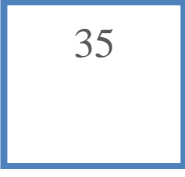

Környezeti

Forrás: Saját kutatás.

Az összes kitöltő 91,3\%-a jelölte meg a gazdasági tényezők témakörét, mint fenntarthatósági tényezőt, amelyre a szálloda figyelmet fordít. A társadalmi tényezőket 53 szálloda, vagyis a minta 66,3\%-a tartotta fontosnak, míg a környezeti tényezőket mindössze 35 szálloda, vagyis 43,8\% emelte ki válaszában. A kutatás eredménye alapján megállapítható, hogy a gazdasági fenntarthatóság egyértelmüen prioritást élvez a magyar szállodák müködése során, és elsődlegesnek tekinthető a többi pillérhez viszonyítva. A második a fontossági sorrendben a társadalmi fenntarthatóság lett, amit a környezeti pillér követ.

2. A magyar szállodák esetében a szállodalánc tagság és a fenntarthatósági stratégia megléte között összefüggés van.

A második hipotézis a fenntarthatósági stratégia megléte, és a szállodalánchoz való tartozás közötti kapcsolatot vizsgálja, és azt feltételezi, hogy a szállodalánc tagság szinte garanciát jelent a fenntarthatósági stratégia meglétére. A részvevő szállodák közül 22 tagja szállodaláncnak. Fenntarthatósági stratégiával a többség rendelkezik, vagyis a vizsgált mintában résztvevő szállodák 61,5\%-a. Ezek közül 15 szálloda rendelkezik írásban megfogalmazott stratégiával, míg 33 szállodának nincs írásba fektetett stratégiája, csak a gyakorlatban alkalmazzak azokat.

1. táblázat: Fenntarthatósági stratégia megléte és szállodalánc-tagság közötti összefüggés

\begin{tabular}{|c|l|l|}
\hline & \multicolumn{2}{|c|}{ Ön tagja szállodaláncnak? } \\
\hline $\begin{array}{c}\text { Rendelkezik a szálloda a fenntarthatóságra } \\
\text { vonatkozó stratégiával? }\end{array}$ & Correlation Coefficient & Sig. (2-tailed) \\
\hline
\end{tabular}

Forrás: Saját kutatás.

Az eredmények alapján elmondható, hogy a második hipotézis bizonyítást nyert, hiszen a rangkorreláció során kapott 0,004 szignifikancia érték 0,05 érték alatti, ezért egyértelmüen megállapítható a kapcsolat a szállodalánchoz tartozás és a fenntarthatósági stratégia megléte között. A korreláció pozitív irányú, tehát a szállodalánc tagság pozitívan befolyásolja a fenntarthatósági stratégia meglétét. A rangkorreláció segítségével a kapcsolat erőssége is kiszámítható, és a 0,322es érték közepes kapcsolatot jelent. Ezért kijelenthető, hogy a szállodalánc tagság közepes kapcsolatban áll a fenntarthatósági stratégia meglétével. 
3. A magyar szállodák esetében a fenntarthatósági stratégia kialakitója és betartatója között kapcsolat van.

A fenntartható stratégiával kapcsolatban mindenképpen lényeges kérdés, hogy a stratégia végül betartásra kerül-e, illetve betartható-e. Az első lépés ennek eldöntéséhez annak vizsgálata, hogy milyen kapcsolat van a stratégia kialakítója és betartatója között. A 48 fenntarthatósági stratégiával valamilyen formában rendelkező szállodából 37 esetben volt a stratégia fenntartásáért felelös személy. A kialakítás esetében, 27 esetben az igazgató, 8 esetben pedig a részleg vezető felel. A szállodaláncok vonatkozásában 5 alkalommal jelölték meg, hogy a láncon belül egy konkrét személy feladatköre, míg 1 hotel alkalmaz külső céget. A betartásért 28 esetben felel a szálloda vezetője, 9 esetben a részlegvezető, 3 esetben teljes, szálloda szintü koordináció van, míg 1 esetben külön személyt alkalmaznak a feladatra.

2. táblázat: Fenntarthatósági stratégia kialakításáért és betartatásáért felelős egyén

\begin{tabular}{|l|l|l|}
\hline & \multicolumn{1}{|l|}{$\begin{array}{l}\text { A szállodában ki felel a fenntartható } \\
\text { stratégia kialakításáért? }\end{array}$} \\
\hline & Correlation Coefficient & Sig. (2-tailed) \\
\hline $\begin{array}{c}\text { A szállodában ki felel a fenntartható stratégia } \\
\text { betartatásáért? }\end{array}$ &, $416^{* *}$ &, 007 \\
\hline
\end{tabular}

Forrás: saját kutatás

A hipotézis vizsgálatakor szintén rangkorrelációt alkalmaztak a kutatók, amelynek eredményeként szignifikáns kapcsolatot állapíthattak meg a szálloda fenntarthatósági stratégiájának kialakítója és betartatásért felelős személye között. A kapcsolatot a 0,007 szignifikancia érték támasztja alá. Az összefüggés pozitív irányú, tehát nem fordított kapcsolat áll fenn a két változó között. A fenntarthatósági stratégia kialakításáért felelős személy és a betartásáért felelős munkatárs között pedig közepesen erős kapcsolatot lehet megállapítani, ami közelebb van az erőshöz, mint a gyenge kapcsolathoz. A fent vázoltakból adódik, hogy a szállodai fenntarthatósági stratégia kialakítója és betartásért felelös alkalmazottja között pozitív, közepes erősségü kapcsolatot lehet megállapítani.

4. A magyar szállodák müködése során a fenntarthatóság társadalmi tényezöje akkor válik fontossá, ha egy részlegvezetö a felelös a társadalmi pillér megvalósitásáért.

A negyedik hipotézis a fenntarthatósági stratégia betartatásának kérdéskörét helyezi a középpontba. Feltételezi, hogy a részlegvezetö, mivel jobban szembesül az emberi tényezővel, ezért a társadalmi fenntarthatóság iránt jobban elkötelezettnek mondható, mint a szálloda felsővezetője, igazgatója.

3. táblázat: A stratégia betartatásáért felelős egyén és az egyes tényezők közötti összefüggés

\begin{tabular}{|l|l|l|}
\hline & \multicolumn{2}{|l|}{$\begin{array}{l}\text { Az alábbi fenntarthatósági tényezők közül melyikre fordít } \\
\text { figyelmet a szálloda? [társadalmi tényezők (pl. helyi } \\
\text { közösség támogatása, munkahelyi közösség erösítése)] }\end{array}$} \\
\hline & Correlation Coefficient & Sig. (2-tailed) \\
\hline Igazgató tartja be &,$- 741^{* *}$ &, 000 \\
\hline Külön személy tartja be &, 154 &, 335 \\
\hline Részlegvezető tartja be &, $480^{* *}$ &, 001 \\
\hline Láncon belül tartják be &, 274 &, 083 \\
\hline
\end{tabular}

Forrás: saját kutatás

A vizsgálat során kapcsolatot találtunk mindkét tényező között, tehát szignifikáns kapcsolat van a fenntarthatóság társadalmi tényezője és az igazgatói betartatás között, valamint a társadalmi pillér és a részlegvezető általi betartatás között. Tehát a kapcsolat szignifikanciája szempontjából nincs különbség a két pozíció között. 
Azonban, ha a kapcsolat irányát vizsgáljuk, akkor látható a különbség; míg a részlegvezető esetében pozitív kapcsolat figyelhető meg, tehát a társadalmi tényezőre akkor fordít több figyelmet a szálloda, ha a részlegvezető tartatja be a stratégia elemeit. Azonban az igazgató esetében ez a kapcsolat fordított irányú, tehát amennyiben az igazgató a betartató, akkor a társadalmi pillér nem kap nagy szerepet, nem kerül a figyelem fókuszába. A kapcsolatok erőssége is különbözően alakul; az igazgató esetében a fordított kapcsolat kifejezetten erősnek mondható, míg a részlegvezető betartatásával közepes a kapcsolat, azonban nagyon közel áll az erős kapcsolat küszöbértékéhez.

\subsection{Következtetések}

A kutatás fö kérdése a szállodai fenntarthatóság müködése és minősége, amelynek gyakorlati megvalósításának vizsgálatát tűzték ki célul a szerzők. A négy hipotézis az elsődleges kutatás alapján a kapott eredmények tükrében elfogadható, a mérhető összefüggések mindegyike szignifikáns eredményt hozott; amely kapcsolatok kimutatása, valamint erősségük feltárása mellett az eredmények interpretációja és gyakorlati hasznosíthatósága is kiemelkedő szerepet kapott a kutatás során.

Az első hipotézis a fenntarthatósági pillérek fontossága közötti különbséget feltételezi, szállodai tapasztalatok és a szakirodalom alapján pedig az az állítás fogalmazódott meg, hogy a gazdasági fenntarthatóság kerül túlsúlyba a másik két tényezővel szemben. A kutatás eredménye is azt mutatja, hogy a magyar szállodákban a gazdasági fenntarthatóság egyértelmüen elsődleges, amelyet a társadalmi és végül a környezeti fenntarthatóság követ. A magyar szállodák átlagára illetve jövedelmezősége alacsonynak mondható akár a szomszédos országokéhoz képest (MSZÉSZ 2020), mindezt számszerü adatokkal a Magyar Szállodák és Éttermek Szövetsége által rendszeres jelleggel készített, Központi Statisztikai Hivatal adataira épülő trendriportja is alátámaszt. Amennyiben csak és kizárólag a közép-kelet-európai régió képezi a vizsgálat tárgyát, úgy a magyarországi szállodák REVPAR-mutatója (Revenue Per Available Room) nettó 22,3 EUR volt a 2020. év augusztus hónapjában, mind a szlovák (29,3 EUR), mind a lengyel szállodák (26,5 EUR) megelőzték teljesítményben hazánkat (MSZÉSZ, 2020). Ezzel párhuzamosan azonban a bérterhek és egyéb adók, illetékek pedig inkább magasak, nem beszélve a magyarországi ÁFA mértékéröl, amely világviszonylatban is jelentős mind a komplex gazdasági ágazatban (EUROPEAN COMMISSION 2020), mind pedig a szükebb turisztikai szektort tekintve is. Egyfajta elörelépésként definiálható ugyanakkor, hogy 2020. januárjától a szálláshely-szolgáltatás 18\%-os ÁFA-kulcsa 5\%-ra csökkent. Az eredmények alapján látható, hogy a gazdasági pillér egyértelmüen dominálja a szállodai fenntarthatósági gyakorlatokat, amiből az következik, hogy bármely bevezetendő fenntarthatósági eszköz a gazdasági fenntarthatóságot semmiképp nem ronthatja.

A második hipotézis a szállodalánc tagság és a fenntarthatósági stratégia megléte közötti kapcsolatot vizsgálja, és feltételezi, hogy a szállodalánchoz tartozó szállodák nagyobb valószínüséggel rendelkeznek fenntarthatósági stratégiával, mint független társaik. A kutatás bizonyította a kapcsolatot a magyar szállodák esetében, tehát a kutatási eredményekből is látszik, hogy a szállodaláncok úttörők a fenntarthatósági stratégiák kialakításában, illetve gyakorlati alkalmazásában.

Számos példa látható a világ vezető szállodaláncai esetében a fenntarthatósági stratégia alkalmazására, például az Accor Planet 21 programja (https://all.accor.com/gb/sustainabledevelopment/index.shtml), vagy a már említett Marriott International illetve a Hilton, InterContinental Hotels Group példaértékü CSR-projektjei (WANG et al, 2020). Itt érdemes azonban megjegyezni, a szállodalánc tagság és a fenntartható stratégia megléte közötti kapcsolat ugyan pozitív, de közepes erősségü, ami azt jelzi, hogy nem kizárólag a szállodalánc tag szállodák rendelkezhetnek fenntarthatósági stratégiával, hanem független társaik előtt is nyitva áll ilyen lehetőség.

A sok magyar, független szállodában dolgoznak olyan munkatársak, akik tapasztalattal rendelkeznek a szállodaláncok müködéséről is, ezért ahogy a sztenderdizálás esetében 
GYURÁCZ-NÉMETH (2015) megállapította, a szállodák vezetőinek ilyen irányú tapasztalata elöre mozdíthatja a fenntarthatósági stratégia ügyét is.

A harmadik hipotézis egy nagyon fontos témára fókuszál, amely a gyakorlati megvalósítás során lényeges tényező lehet. A fenntarthatósági stratégia kialakítója és betartatója közötti kapcsolatot vizsgálták a kutatók, amelynek eredménye összefüggést mutatott a két tényező között. Ez a gyakorlatban azt jelenti, hogy általában az a személy alkotja a fenntarthatósági stratégiát, aki be is tartatja azt. Ez a kapcsolat, ismerve a szállodai hierarchia alacsony szintjét nem meglepő, mivel egy feladat általában egy adott alkalmazott hatás- és felelősségi körébe tartozik. A fenntarthatósági gyakorlat is biztosan dolgozói feladatkör részét képezi, a legtöbb esetben nem létezik külön részleg a fenntarthatósági feladatok kezelésére. Emellett elmondható, hogy a szállodai müködés szempontjából hasznos, hogy a kialakító és a betartató ugyanaz, mivel így a stratégia ismerője, a kialakító személye, a háttéradatok ismerője az, aki a betartást is koordinálja. A szálloda múködése kifejezetten sokrétü, a feladatok is olyan embereket igényelnek, akik bizonyos területekhez kiválóan értenek, ezért lényeges, hogy olyan szakember alkossa és tartassa be a fenntarthatósági stratégiát, aki a terület és a fenntarthatóság szakértője is.

Az utolsó hipotézis a társadalmi fenntarthatósági pillérek fontossága és betartató személye közötti kapcsolatot vizsgálta, és azt állította, hogy a részlegvezető betartatása esetén a társadalmi fenntarthatóság fontossága növekszik, viszont ugyanez a kapcsolat a szálloda igazgatójának esetében már inkább fordítva működik. A hipotézisvizsgálat igazolta is a feltételezést, tehát a részlegvezetők esetében ténylegesen igaz, hogy mivel közvetlenül irányítják a részlegükhöz tartozó dolgozókat és látják személyes, valamint esetleges szakmai problémáikat is, ezért a társadalmi felelősségvállalás fontosabbá válik. A szálloda vezetője esetében a tényezők közötti kapcsolat viszont fordított, tehát a szállodaigazgató számára már a társadalmi fenntarthatóság nem nevezhető fontosnak. Ebböl adódóan kijelenthető, hogy sokkal célszerübb a szállodaigazgatónak a részlegvezetőket megbízni a társadalmi fenntarthatósággal kapcsolatos feladatokkal, mint a saját kezükbe venni a téma koordinálását.

\section{4. Összegzés}

A kutatócsapat vizsgálatának eredményei értékes elméleti és gyakorlati implikációkkal támogatják a döntéshozók munkáját. A kutatás tehát rávilágított, hogy a vizsgált magyarországi szállodák esetében a fenntarthatóság témakörén belül a gazdasági pillér élvez prioritást. Mindez a mai, kihívásokkal teli és már gazdasági válságként definiálható környezetben hatványozottan érvényesül. Profitorientált vállalat esetében a versenyképesség és sikeresség számszerü adatokkal alátámasztható, kulcskérdés a jövedelmezőség. Amennyiben adott szálloda müködése gazdasági szempontból biztosított, akkor tud a tulajdonosi és/vagy üzemeltetői kör a társadalmi és a környezeti aspektusokra is koncentrálni.

A gyakorlatban nagyon fontos - társadalmi tényezőként -, hogy adott szálloda élőmunkaerőigényes mivoltából fakadóan helybeli lakosok számára munkahelyet teremt közvetlenül, közvetve pedig széles beszállítói kör számára jelenthet megélhetési forrásbiztosítást.

A környezeti fenntarthatósági gyakorlat tárháza kimeríthetetlen: a villamos energia fogyasztásának (energiatakarékos izzók használata) és a vízfelhasználás csökkentésén (folyamatos monitorozás például mosogatógépek esetében; optimális textilgazdálkodás) keresztül a hatékony hulladékgazdálkodásig (szelektív hulladékgyüjtés, újrahasznosított csomagolóanyagok, ételhulladék mennyiségének csökkentése) számtalan lehetőség adott.

A szállodaláncok esetében a fenntarthatósági stratégia megléte, betartása, monitorozása sokkal inkább jelen van, mint a kisebb, független házak esetében. Azonban fontos megjegyezni, hogy a kapcsolat csak közepes erősségü, tehát vannak olyan független intézmények, amelyek alkalmaznak fenntarthatósági stratégiát. Ebből adódóan a lánchoz nem tartozó szállodák számára ez a lehetőség és a fenntarthatóság alkalmazására ugyanúgy nyitott, mint a szállodaláncok tagjai számára. 
A gyakorlat szempontjából is érdekes eredmény a létrehozó és betartató közötti összefüggés, amelyre a kutatás rávilágított. Ebböl adódóan érdemes - a társadalmi pillér tekintetében biztosan részlegvezetői szintre emelni a stratégia kidolgozását. Kiemelendő, hogy a szállodák azt találják leghatékonyabb metódusnak, ha a fenntarthatósági stratégia kialakítója és betartatója ugyanaz a személy.

Összességében elmondható, hogy a szállodák fenntarthatósági törekvései már a gyakorlatban is láthatóak, elsősorban a gazdasági pillérrel foglalkoznak és kifejezetten fenntarthatósági stratégia inkább a szállodaláncoknál található meg. Hatékonynak tartják a mindennapi müködés során, ha a fenntarthatósági stratégia alkotója és betartatója ugyanaz, továbbá előnyös a megvalósítás szempontjából, ha a részlegvezető felelős a társadalmi fenntarthatóság betartatásáért.

A kutatás korlátjaként nevezhető meg az elemszám, amely ugyan alacsonynak nem mondható, de reprezentatív jelleggel nem bír sem lokáció, sem szálloda típus szempontjából. Mivel egy előre meghatározott, konkrét jelenség meglétét kívánta felmérni a kutatói csapat, ezért a kutatási kérdések főként nominális eredményt hoztak. Egy jövőbeli felmérésnél érdemes lenne akár feltáró kutatást végezni kompetens résztvevőkkel, vagy egy az eredmények alapján létrehozott magas mérési változókat eredményező kérdőív segítségével tovább bővíteni a kutatást.

Jövőbeli kutatási irányként a COVID járvány alatti és utáni fenntarthatósági magatartás vizsgálatát tủzte ki célul a kutatói csapat a fogyasztók fenntarthatósághoz való viszonya és ennek változása mellett.

\section{Irodalomjegyzék}

ASADI, S. - OMSALAMEH POURHASHEMI, S. - NILASHI, M. - ABDULLAH, R. - AMAD, S. - YADEGARIDEHKORDI, E. - ALJOJO, N. - RAZALI, N. S. (2020) Investigating influence of green innovation on sustainability performance: A case on Malaysian hotel industry. Journal of Cleaner Production, Vol. 258, 2020, 120860

ÁSVÁNYI, K. - CHAKER, H. - VARGA, Á. (2020): „Szép szavak, jó tettek?” A párizsi top zöld szállodák CSR értékeinek és tevékenységének vizsgálata, Turizmus Bulletin, XX. évfolyam, 1. szám 2020, pp. 4-15

BHOCHIBHOYA, S. - PIZZOL, M. - MARINELLO, F. - CAVALLI, R. (2020): Sustainability performance of hotel buildings in the Himalayan region. Journal of Cleaner Production, Vol. 250, 2020, 119538

BUFFA, F. - Franch, M. - Rizio, D. (2018): Environmental management practices for sustainable business models in small and medium sized hotel enterprises, Journal of Cleaner Production, Vol. 194., 2018, pp. 656-664

CASTELLANI, V. - SALA, S. (2009): Sustainable Tourism as a Factor of Local Development. First edition, Tangram Edizioni Scientifiche Trento, Gruppo Editoriale Tangram Srl, Trento, ISBN: 9788864580012, pp. 14-27

CHEN, L. (2019): Hotel chain affiliation as an environmental performance strategy for luxury hotels, International Journal of Hospitality Management, Vol. 77. 2019, pp. 1-6

D'ACUNTO, D. - TUAN, A. - DALLI, D. - VIGLIA, G. - OKUMUS, F. (2020): Do consumers care about CSR in their online reviews? An empirical analysis. International Journal of Hospitality Management, Vol. 85, 2020, 102342

DANI, R. - TIWARI, K. - NEGI, P. (2021): Ecological approach towards sustainability in hotel industry. Materials Today: Proceedings, 2021

FLEISCHER, T. (2014): A fenntarthatóság fogalmáról. In: Közszolgálat és fenntarthatóság. Nemzeti Közszolgálati Egyetem, Budapest, 2014

GYURÁCZ-NÉMETH, P. (2014): A magyar szállodák környezettudatos innovációi. Turizmus. Bulletin Vol: 16, Issue 3-4, 2014, pp. 68-75 
GYURÁCZ-NÉMETH, P. (2015): Service Delivery Standardisation and Customisation in the Hungarian Hotels = A szolgáltatási folyamat sztenderdizálása és testreszabása a magyar szállodákban, Gazdálkodás- és Szervezéstudományok DI, Pannon Egyetem, Veszprém, 2015

HACKING, T. - GUTHRIE, P. (2008): A framework for clarifying the meaning of Triple BottomLine, Integrated, and Sustainability Assessment. Environmental Impact Assessment Review, 28, 2008, pp 73-89

JONES P. - HILLIER, D. - COMFORT, D. (2013): Sustainability in the global hotel industry. International Journal of Contemporary Hospitality Management, 2013, Vol. 26 Iss 1, pp. 5 - 17 KANG, K. H.-STEIN, L. - HEO, C. Y. - LEE, S. (2012): Consumers' willingness to pay for green initiatives of the hotel industry. International Journal of Hospitality Management, Vol 31 Issue 2., 2012, pp. 564-572

KEREKES, S. (1998): A környezetgazdaságtan alapjai. Budapest, 1998. Online elérhetőség: http://mek.oszk.hu/01400/01452/html/

KHATTER, A. - MCGRATH, M. - PYKE, J. - WHITE, L. - LOCKSTONE-BINNEY, L. (2019): Analysis of hotels' environmentally sustainable policies and practices. International Journal of Contemporary Hospitality Management, Vol. 31, 2019, No. 6, pp. 2394-2410

KULARATNE, T. - WILSON, C. - MÅNSON, J. - HOANG, V. - LEE, B. (2018): Do environmentally sustainable practices make hotels more efficient? A study of major hotels in Sri Lanka, Tourism Management, Vol. 71, 2018, pp. 213-225

KULARATNE, T. - WILSON, C. - MANSSON, J. - HOANG, V. - LEE, B. (2019): Do environmentally sustainable practices make hotels more efficient? A study of major hotels in Sri Lanka. Tourism Management, Vol. 71, 2019, pp. 213-225

LATIF, K.F. - PÉREZ, A. - SAHIBZADA, U. F.(2020): Corporate social responsibility (CSR) and customer loyalty in the hotel industry: A cross-country study, International Journal of Hospitality Management, Vol. 89, 1025652020

MOLNÁR, T. (2015): Empirikus Területi Kutatások. 1st ed. Budapest: Akadémiai Kiadó Zrt, 2015, pp.103-104

MUCHARREIRA, P.R. - ANTUNES, M.G. - ABRANJA, N. - M.R. TEXEIRA JUSTINO QUIRÓS, J.T. (2019): The relevance of tourism in financial sustainability of hotels, European Research on Management and Business Economics, Vol. 25, 2019, pp. 165-174

MUCHARREIRA, P.R. - ANTUNES, M.G. - ABRANJA, N. - JUSTIONO, M.R.T. - QUIRÓS, J.T. (2019): The relevance of tourism in financial sustainability of hotels. European Research on Management and Business Economics, Vol. 25, 2019, pp. 165-174

PENG, N. - CHEN, A. (2013): Luxury hotels going green - the antecedents and consequences of consumer hesitation. Journal of Sustainable Tourism, Volume 27, 2019 - Issue 9

PRUD'HOMME, B. - RAYMOND, L. (2013) Sustainable development practices in the hospitality industry: An empirical study of their impact on customer satisfaction and intentions. International Journal of Hospitality Management, Vol. 34, 2013, pp. 116-126

REES, WILLIAM. E. (2002): Globalization and Sustainability: Conflict or Convergence? Bulletin of Science, Technology \& Society, Vol. 22, No. 4, August 2002, pp. 249-268

REID, S. - JOHNSTON, N. - PATIAR, A. (2020): Coastal resorts setting the pace: An evaluation of sustainable hotel practices, International Journal of Hospitality Management, Vol. 33. 2020, pp. $11-22$

SANTOS, R.A. - MEXAS, M.P. - MEIRINO, M.J. - SAMPAIO, M.C. - COSTA, H.G. (2020): Criteria for assessing a sustainable hotel business, Journal of Cleaner Production, Vol. 2622020 SLOAN, P. - SIMONS-KAUFMAN, C. - LEGRAND, W. (2012): Sustainable Hospitality and Tourism as Motors for Development. Case studies from developing region of the world, First Publish, Routledge, Oxon, pp. 14-21

UNITED NATIONS ENVIRONMENT PROGRAMME, WORLD TOURISM ORGANIZATION (2005): Making Tourism More Sustainable. A Guide for Policy Makers, 2005. 
WANG, C. - HU, R. - ZHANG, T. (2020): Corporate social responsibility in international hotel chains and its effects on local employees: Scale development and empirical testing in China, International Journal of Hospitality Management, Vol. 90. 2020

WANG, P. - KIM, P. - MILNE, S. (2020): The impacts of leader-member guanxi and its differentiation on hotel employees moderated by Confucian values, International Journal of Hospitality Management, Vol. 91. 2020

\section{Egyéb források:}

Accor Hotels hivatalos oldal

https://all.accor.com/gb/sustainable-development/index.shtml

[Letöltés: 2020. október 14.]

European Commission: „VAT rates”

https://files.taxfoundation.org/20200108144805/VAT-Rates-in-Europe-2020-01.png

[Letöltés: 2020. október 15.]

Központi Statisztikai Hivatal: A Fenntartható Fejlődési Célok és az Agenda 2030 keretrendszer.

https://www.ksh.hu/sdg

[Letöltés: 2021. június 18.]

Magyar Szállodák és Éttermek Szövetsége: Trendriport 2020. augusztus

http://www.hah.hu/files/4416/0248/6769/Trendriport_2020._augusztus.pdf

[Letöltés: 2020. október 14.]

Marriott International hivatalos oldal

https://serve360.marriott.com/

[Letöltés: 2020. október 16.]

Statistics Solutions. 2020. Correlation (Pearson, Kendall, Spearman) - Statistics Solutions. [online]

https://www.statisticssolutions.com/correlation-pearson-kendall-spearman/

[Letöltés: 2020. szeptember 23.]. 